ホルスタイン種雄去勢肥育牛の濃厚飼料要求率扰よび 第一胃液性状に及ぼすサリノマイシンとモネンシンの影響

\author{
脇田正彰 - 小林泰男 ・星野貞夫 \\ 北林栄宗* ・橋村元男**.工藤英彦** \\ 三重大学農学部, 津市 514 \\ *三重県経済農業協同組合連合会, 津市 514 \\ **科研製薬株式会社, 東京都中央区 103
}

(1986，11. 20 受付)

\begin{abstract}
要 約 ホルスタイン種雄去勢牛 28 頭を供試して, サリノマイシン（SL）およびモネンシン（MN） の飼料要求率および第一胃液性状（第一胃液 $\mathrm{pH}$, 揮発性脂肪酸 (VFA) 濃度, アンモニア濃度およ びプロトゾア数）に及ぼす影響を検討した. 供試牛は, 無添加（対照), 20 ppm SL 添加, 30 ppm SL 添加, $30 \mathrm{ppm} \mathrm{MN}$ 添加の濃厚飼料を給与する 4 処理区に等しくなるよう分け, 7 か月齢から 292 日間 それぞれの濃厚飼料と粗飼料として稲わらを自由採食させた。最終時体重と平均 1 日当りの増体量は SL または MN 給与によって影響されなかったが，濃厚飼料の摂取量は減少し， SL-20 ppm, SL-30 ppm および MN-30ppm 添加給与は濃厚飼料の要求率がそれぞれ7,2および $8 \%$ 改善された. 現 在わか国で飼料添加物として指定されている SL の $20 \mathrm{ppm}$ とN の $30 \mathrm{ppm}$ 添加給与の勃果には, 有意な差は見られなかった。飼料要求率改善の割合は飼養期間中, 必ずしも一定でなかった．試験前半 の第一胃液性状には, VFA 組成割合を除いて SL および MN 給与による変更はなかったが, 試験後 半には SL および MN 給与によって第一胃液 $\mathrm{pH}$ ，アンモ二ア濃度, および酢酸/プロピオン酸 (A/ P）比が低下した。試験開始時のプロトゾア総数は $10^{4} / \mathrm{m} l$ 以下でイオノフォア給与によってもほとん ど影響がなかった。
\end{abstract}

日畜会報， $58(5) ： 396-402 ， 1987$.

モネンシン(MN)は, Streptomyces cinnamonesis より生産される抗生物質で, 生体膜のイオン透過に対し て影響を与え，イオノフォア上総称されているものの一 種である.MN は第一胃内微生物に作用し，1）プロピ オン酸生産の增加之酢酸および酪酸生産の減少 $\left.{ }^{1-5} 2\right)$ メタン生成の抑制 ${ }^{3-5)} 3$ ) タンパク質分解と脱アミノ活 性の抑制 ${ }^{1,5)}$ など, 肥育牛の飼料利用纪有利之考えられ る方向へ第一胃内発醉を変更させ, 肥育牛に給与すると 飼料効率を約 $10 \%$ 改善する ${ }^{2,6-8)}$ 乙とから, 肥育牛の第 一胃内発醉の制御を通して生産性を改善する化学物質と して注目され，てれまでに数多くの研究が行なわれてい る.

一方, Streptomyces albus より生産されるサリノ マイシン（SL）もイオノフォアの一種で, 生体膜のイ オン透過に対する影響は MN と若干相違するが, 反す

日畜会報，58（5）：396-402

う家畜に給与した場合に第一胃内発醉や飼料利用に対し て, MN と同様の作用効果が示されている ${ }^{8-10)}$. しかし, MN に比べると試験例数は少なく, 両者を直接比较し た試験はみられない，また，MN ゃSL を長期間給与 した試験において, 後半に飼料効率改善効果か認められ なくなったてとを指摘する報告9,11) がある. MN と SL は, 昭和 60 年 10 月にわが国であ肉牛用の飼料添加物に 指定され, それぞれ $30,20 \mathrm{ppm}$ の濃度で利用されて いるが，米国のフィードロット方式に比へ肥育期間の長 いわか国の飼養方式では，乙の点に関してあ検討が必要 である.

本研究は, 眃厚飼料多給型の乳用種雄去勢牛に SL 20 ppm および $30 \mathrm{ppm}, \mathrm{MN} 30 \mathrm{ppm}$ を濃厚飼料儿添加 して 292 日間給与した時の増体, 飼料要求率および第一 胃内性状について比較検討した。 
肥育牛へのイオノフォア給与効果

Table 1. Chemical composition of concentrates (\%)

\begin{tabular}{lcccccc}
\hline \hline Feed & Moisture & $\begin{array}{c}\text { Crude } \\
\text { protein }\end{array}$ & $\begin{array}{c}\text { Crude } \\
\text { fat }\end{array}$ & NFE & $\begin{array}{c}\text { Crude } \\
\text { fiber }\end{array}$ & $\begin{array}{c}\text { Crude } \\
\text { ash }\end{array}$ \\
\hline Formula feed & 12.3 & 12.4 & 3.8 & 62.8 & 3.2 & 5.5 \\
Crushed barley & 14.8 & 11.3 & 1.7 & 66.4 & 3.7 & 2.1 \\
Wheat bran $^{\mathrm{a}}$ & 11.9 & 17.5 & 5.1 & 53.2 & 7.7 & 4.6 \\
Crushed milo $^{\mathrm{b}}$ & 12.9 & 9.4 & 3.1 & 70.8 & 2.1 & 1.7 \\
\hline
\end{tabular}

a: Used for the first 192 days.

b: Used from 193 to 292 days.

\section{材料およひ方法}

ホルスタイン種雄去勢牛（約 7 か月齢, 平均体重 265 kg） 28 頭を, 対照区と 3 試験区に 7 頭ずつ無作為に分 け群飼した。試硂区には, 給与涱厚眗料に対し SL を 20 ppm（SL-20 ppm 区）と $30 \mathrm{ppm}(\mathrm{SL}-30 \mathrm{ppm} 区)$, MN を 30 ppm（MN-30 ppm 区）添加して給与した. 濃厚飼料は表 1 に示した化学組成で, 試験開始日より 192 日までは肥育牛用配合帥司料と圧ぺん大麦およびフスマを 3:1:1の比率で眍合したものを, 193 日目から試験終 了時の 292 日目まではフスマに替えて压ぺんマイロを同 比率で匢合したものを不断給与した。粗飼料として稲わ らを 1 日 1 頭当り $1.4 \sim 1.7 \mathrm{~kg}$ 給与した. SL と MN は，規定浱度になるように給与洤厚飼料に添加し，ペレ ットに調製して給与した。

体重と濃厚飼料摄取量は，0（試験開始日），61，119, 187，244，292 日目（試験終了日）に測定し，それぞれ の測定日の期間を順次 I 期 (61 日間)，II 期 (58 日間), III期 (68 日間), IV 期 (57 日間)， V 期 (48 日間) とし た. また体重測定日に経口式ルーメンカテーテル（ルミ ナー：富士平工業 $\mathrm{KK}$ ) で第一胃液を採取して $\mathrm{pH}, ア$ ンモニア態窒素 $\left(\mathrm{NH}_{3}-\mathrm{N}\right)$, 揮発性脂肪酸 (VFA), プ ロトソアを定量, 計数した。 $\mathrm{pH}$ は試料採取後直ちにガ

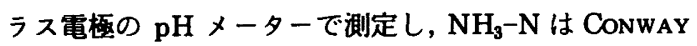
の微量拡散法 ${ }^{12)}$ で, VFA は須藤のガスクロマトグラム 法 ${ }^{10}$ で定量した。プロトソアは，栗原・武智の方法 ${ }^{12)}$ で染色固定して計数した.

\section{䓰果}

体重, 1 日当りの増体量 (日增体重), 謈厚飼料摃取 旦および浱厚飼料要求率の結果を表 2 亿示した. 体重は すべての区間で有意な差はなかったが，SL-30 ppm 区 で後半個体差が大きくなった，日增体量は，一部区間で 有意差が見られたが一定の頓向はなく，通算では全区と あはぼ等しい值であった。濃厚飼料摄取量は, SL-20 $\mathrm{ppm}$ 区と MN-30 ppm 区はいずれの期においても対 照区より少なく，特に II 期，IV期およびV期で著しく減 少し, 全期間では有意な減少 $(\mathrm{P}<0.05)$ がみられた。 しかし, SL-30 ppm 区の摄取量はV期で隇少したが, 通算ではあまり大きいあのではなかった，濃厚飼料の要

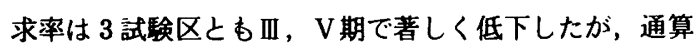
の要求率は，SL-20 ppm 区, SL-30 ppm 区および MN-30 ppm 区でそれぞれ 7，2，8\%改善された。

第一胃液の $\mathrm{pH}, \mathrm{NH}_{3}-\mathrm{N}$ 謈度およびプロトゾア数を 表 3 亿, VFA 亿関する結果を表 4 亿示した。 pH およ び $\mathrm{NH}_{3}-\mathrm{N}$ 濃度は試験前半では対照区と 3 試験区との 差は小さかったが, 後半ではその差が大きくなって 3 試 験区は対照区に比べ187，292 日目では低く，244 日目 では高くなった $(\mathrm{P}<0.05) . \mathrm{pH}, \mathrm{NH}_{3}-\mathrm{N}$ 濃度とも 3 試 験区間で有意な差が認められたが, 処理による一定の傾 向はなかった。観察されたプロトゾアはすべて Entodinium 属で, 試験前半は非常に少なく後半に増加したが, 個体差が非常に大きかった。 292 日目では MN-30 ppm 区は対照区および SL $-20 \mathrm{ppm}$ 区より多かった。（P $<0.05)$.

総 VFA 浱度も前半は対照区と 3 試験区との間に大 きな差はなかったが，3 試験区は後半の $187 ， 292$ 日目 で対照区より高く，244日目は逆に低くなった（P $<0.05)$. VFA 組成割合は, 61 日目の試料から対照区 と 3 試験区との間に明らかな差が見られ，3 試験区はプ ロピオン酸割合が增加し，酢酸または酪酸割合が減少し た $(\mathrm{P}<0.05)$. これらの差は前半より後半で大きくな った。酢酸とプロピオン酸 (A/P) 比は前半全区とす 非常に低い値であったが，3 試験区が試験終了時まで低 い值を持続したのに対し，対照区では後半に高まって有 意な差となった。 $(\mathrm{P}<0.05)$ 。また, SL-20 ppm 区は $\mathrm{MN}-30 \mathrm{ppm}$ 区より A/P 比か有意 $(\mathrm{P}<0.05)$ に低く なった。 
Table 2. Effects of salinomycin(SL) and monensin(MN) on body weight, daily gain, concentrate intake and feed conversion of concentrate (Mean \pm standard error $n=7$ )

\begin{tabular}{|c|c|c|c|c|}
\hline Days or periods & Control & SL-20 ppm & $\mathrm{SL}-30 \mathrm{ppm}$ & $\mathrm{MN}-30 \mathrm{ppm}$ \\
\hline \multicolumn{5}{|c|}{ Body weight (kg) } \\
\hline 0 & $267.3 \pm 18.9$ & $266.1 \pm 24.3$ & $265.7 \pm 18.5$ & $262.1 \pm 19.5$ \\
\hline 61 & $387.0 \pm 19.5$ & $387.1 \pm 14.4$ & $382.0 \pm 18.3$ & $386.9 \pm 5.3$ \\
\hline 119 & $469.6 \pm 21.6$ & $465.9 \pm 22.3$ & $462.0 \pm 28.7$ & $462.6 \pm 9.8$ \\
\hline 187 & $536.6 \pm 15.2$ & $538.3 \pm 22.0$ & $537.5 \pm 44.8$ & $542.4 \pm 8.1$ \\
\hline 244 & $595.6 \pm 23.2$ & $588.7 \pm 25.2$ & $589.5 \pm 57.2$ & $595.1 \pm 19.3$ \\
\hline 292 & $640.7 \pm 6.1$ & $635.9 \pm 29.3$ & $637.7 \pm 59.7$ & $637.3 \pm 19.2$ \\
\hline \multicolumn{5}{|c|}{ Daily gain (kg/head/day) } \\
\hline I & $1.97 \pm 0.38$ & $1.98 \pm 0.49$ & $1.91 \pm 0.11$ & $2.04 \pm 0.33$ \\
\hline II & $1.42 \pm 0.13$ & $1.36 \pm 0.28$ & $1.38 \pm 0.26$ & $1.31 \pm 0.22$ \\
\hline III & $0.99 \pm 0.12$ & $1.06 \pm 0.09^{* * a}$ & $1.11 \pm 0.34^{\mathrm{b}}$ & $1.17 \pm 0.06^{\mathrm{ab}}$ \\
\hline IV & $1.04 \pm 0.41$ & $0.88 \pm 0.19$ & $0.91 \pm 0.27$ & $0.92 \pm 0.27$ \\
\hline $\mathrm{V}$ & $0.78 \pm 0.23$ & $0.98 \pm 0.17$ & $1.01 \pm 0.20$ & $0.88 \pm 0.16$ \\
\hline$I-V$ & $1.27 \pm 0.06$ & $1.27 \pm 0.15$ & $1.27 \pm 0.16$ & $1.28 \pm 0.09$ \\
\hline \multicolumn{5}{|c|}{ Concentrate intake ( $\mathrm{kg} /$ head/day) } \\
\hline I & $9.06(100)^{+}$ & $8.81(97)^{+}$ & $8.77(97)^{+}$ & $8.90(98)^{+}$ \\
\hline II & $10.15(100)$ & $9.21(91)$ & $10.29(101)$ & $9.21(91)$ \\
\hline III & $8.91(100)$ & $8.74(98)$ & $8.92(100)$ & $8.74(98)$ \\
\hline IV & $9.61(100)$ & $8.62(90)$ & $9.36(97)$ & $8.42(88)$ \\
\hline $\mathrm{v}$ & $9.72(100)$ & $8.57(88)$ & $9.17(94)$ & $8.57(88)$ \\
\hline $\mathrm{I}-\mathrm{V}$ & $9.45(100)$ & $8.80(93)^{*}$ & $9.27(98)$ & $8.78(93) *$ \\
\hline \multicolumn{5}{|c|}{ Feed conversion (concentrate intake/gain) } \\
\hline I & $4.60(100)^{+}$ & $4.45(97)^{+}$ & $4.59(100)^{+}$ & $4.36(95)^{+}$ \\
\hline II & $7.14(100)$ & $6.77(95)$ & 7. $46(104)$ & $7.03(98)$ \\
\hline III & $9.00(100)$ & $8.25(92)$ & $8.03(89)$ & $7.47(83)$ \\
\hline IV & $9.24(100)$ & $9.80(106)$ & 10.29 (111) & $9.15(99)$ \\
\hline $\mathrm{V}$ & $12.46(100)$ & $8.74(70)$ & $9.08(73)$ & $9.73(78)$ \\
\hline$I-V$ & 7. $44(100)$ & $6.93(93)$ & $7.30(98)$ & $6.86(92)$ \\
\hline
\end{tabular}

*,** In each row differences from control are significant at 5 and $1 \%$ level.

$a, b$ Values followed by different letters differ significantly at $5 \%$ level.

+ Values in parenthesis are relative values when the corresponding controls are 100.

\section{考察}

BERGEN と BATES $^{8)}$ によると, MN では 5〜12\%, $\mathrm{SL}$ では $7 \%$ 程度の飼料効率改善効果があり, 本試験て あ SL-20 ppm または $\mathrm{MN}-30 \mathrm{ppm}$ 添加給与で濃厚飼 料要求率がそれぞれ $7 \%$ と $8 \%$ 改善され（表 2) て, 現 在わか国で指定されている両イオノフォアの添加濃度で ある両区の効果がほぼ同等であるてとを示した。 また， これらの改善効果は多くの報告と同様に，増体量に差が 見られずに飼料摂取量の著しい減少に起因するものであ った（表 2). しかし,川島ら ${ }^{11)}$ が MNを，中嶋ら”が SL を長期間給与した試験の結果とは異なり, 改善勃果
は試験前半に限られたあのでなく，期間により大きな差 が見られた（表 2).

本試験の場合, 前半の第一胃液性状は, 全区ともプロ ピオン酸割合が $40 \%$ 以上を占め酢酸割合が $50 \%$ 以下で あり， $\mathrm{A} / \mathrm{P}$ 比がきわめて低い. また, $\mathrm{pH}$ 值は低めで, プロトゾアも Entodinium 属のみが低密度で観察され た（表 3，4）ことから，一般に言われている濃厚飼料 多給に適応した第一胃液性状であったと推定される. 後 半になって3 試験区は VFA 濃度の低下と $\mathrm{pH}$ の上昇 傾向が見られたが， A/P 比は依然として低い值を維持 し続けた。一方, 対照区は 182 日目と 292 日目で A/P 比が高く、VFA 潧度か顕著に低く、さらに $\mathrm{NH}_{3}-\mathrm{N}$ 浱 
Table 3. Effects of salinomycin(SL) and monensin(MN) on ruminal $\mathrm{pH}$, anmonia nitrogen concentration and protozoa number (Mean \pm standard error $n=7$ )

\begin{tabular}{|c|c|c|c|c|}
\hline Days & Control & $\mathrm{SL}-20 \mathrm{ppm}$ & SL-30 ppm & $\mathrm{MN}-30 \mathrm{ppm}$ \\
\hline \multicolumn{5}{|l|}{$\mathrm{pH}$} \\
\hline 0 & $6.12 \pm 0.16$ & $5.85 \pm 0.20$ & $6.20 \pm 0.21$ & $6.18 \pm 0.12$ \\
\hline 61 & $6.11 \pm 0.20$ & $6.16 \pm 0.20^{\mathrm{a}}$ & $6.73 \pm 0.16^{* b}$ & $6.44 \pm 0.13^{\mathrm{ab}}$ \\
\hline 119 & $5.91 \pm 0.15$ & $6.13 \pm 0.23$ & $6.38 \pm 0.15^{*}$ & $6.11 \pm 0.17$ \\
\hline 187 & $7.01 \pm 0.06$ & $6.61 \pm 0.08^{* * a}$ & $6.13 \pm 0.12^{* * * b}$ & $6.66 \pm 0.07^{* * a}$ \\
\hline 244 & $6.31 \pm 0.13$ & $6.81 \pm 0.04^{* *}$ & $6.83 \pm 0.07^{* *}$ & $6.69 \pm 0.06^{*}$ \\
\hline 292 & $6.98 \pm 0.12$ & $6.55 \pm 0.15^{* a}$ & $6.69 \pm 0.14^{\mathrm{ab}}$ & $6.74 \pm 0.07^{b}$ \\
\hline \multicolumn{5}{|c|}{ Ammonia nitogen concentration $(\mathrm{mg} / \mathrm{d} l)$} \\
\hline 0 & $12.31 \pm 2.10$ & $17.70 \pm 3.14$ & $17.62 \pm 1.78$ & $14.64 \pm 1.73$ \\
\hline 61 & $4.59 \pm 1.73$ & $3.33 \pm 0.44$ & $4.39 \pm 0.96$ & $3.36 \pm 0.42$ \\
\hline 119 & $4.23 \pm 1.05$ & $5.49 \pm 1.23$ & $5.49 \pm 1.03$ & $3.90 \pm 0.74$ \\
\hline 187 & $6.72 \pm 1.58$ & $3.23 \pm 0.50^{*}$ & $3.01 \pm 0.75^{*}$ & $3.33 \pm 0.61^{*}$ \\
\hline 244 & $1.71 \pm 0.33$ & $4.74 \pm 0.81^{* * a b}$ & $4.53 \pm 0.40^{* * a}$ & $2.82 \pm 0.36 * b$ \\
\hline 292 & $8.27 \pm 0.41$ & $2.76 \pm 0.75^{* * *}$ & $2.08 \pm 0.77^{* * *}$ & $3.38 \pm 0.63^{* * *}$ \\
\hline \multicolumn{5}{|c|}{ Protozoa number $\left(\times 10^{3} / \mathrm{m} l\right.$ rumen fluid $)$} \\
\hline 0 & $1.21 \pm 0.47$ & $1.00 \pm 0.66$ & $1.10 \pm 0.24$ & $2.08 \pm 1.02$ \\
\hline 61 & $0.29 \pm 0.15$ & $2.79 \pm 1.36$ & $8.67 \pm 6.75$ & $5.47 \pm 2.37$ \\
\hline 119 & $6.07 \pm 2.48$ & $15.57 \pm 9.95$ & $6.25 \pm 2.21$ & $41.29 \pm 26.92$ \\
\hline 187 & $21.07 \pm 11.07$ & $15.07 \pm 6.22$ & $26.17 \pm 15.90$ & $19.93 \pm 5.60$ \\
\hline 244 & $39.50 \pm 17.09$ & $61.43 \pm 43.29$ & $41.73 \pm 22.76$ & $276.21 \pm 110.61$ \\
\hline 292 & $56.75 \pm 25.46$ & $36.14 \pm 21.18^{\mathrm{a}}$ & $85.83 \pm 26.81^{\mathrm{ab}}$ & $247.71 \pm 81.16^{* b}$ \\
\hline
\end{tabular}

$*, * *, * * *$ In each row differences from control are significant at 5,1 and $0.1 \%$ level.

${ }^{a, b}$ In each row values followed by different letters differ significantly at $5 \%$ level.

度が高くなり, $\mathrm{pH}$ は 7.0 亿近くなっており（表 3，4）， 前半まで維持されていた第一胃液性状が何らかの要因で 変化したものと推察される. 試験前半で観察されたよう なプロピオン酸生産優勢型の発酪状態を維持している時 の細菌丵は，潄粉分解菌群之有機酸利用菌群が優先的に 存在し，低 $\mathrm{pH}$ により紻維分解菌群などの生育か抑制 されていると言われている ${ }^{13)}$. 一方, MN は第一胃内細 菌位して選択的に作用し，メタン生産に間接的に関与 する Ruminococcus albus, $R$. flavefaciens, Butyrivirio fibrisolvensなどの生育增殖を抑制するが, プ ロピオン酸の生産を導く Bacteroides succinogenes, B. ruminicola, Selenomonas ruminantium, Anaerovibrio lipolytica, Magasphera elsdenii 飞は阻害 作用が少ないと報告されている ${ }^{14,15}$. 前半に第一胃液性 状や飼料要求率に大きな差が現われなかったてとから, プロピオン酸生産優勢型の発醉を維持している場合には, イオノフォア給与の作用効果が小さいととあ考えられる. ての点からイオノフォアの給与効果の変動要因として, 単位体重当りのイオノフォア摂取量, 第一胃内微生物の
イオノフォア耐性, 給与飼料の種類などの他に，第一胃 内微生物の存在様式との関連についても，今後検討が必 要である.

本試験の対照区の第一胃液性状は後半大きく変動した が，SL および MN を給与した場合には比较的安定し た状態を維持しており，(表 3，4），てれは SLや MN 亿鼓脹症 $^{16-18)}$ 乳酸アシドース ${ }^{19)}$ など第一胃内異常発酵 の防止または治療勃果があるという報告と関連があるか あしれない．また，MNにはトリプトファン分解産物 の3-メチルインドールが関与するとみられる肺水腫, 肺気腫の予防効果が示唆されている ${ }^{20)}$. わが国のように 濃厚眗料を長期間多給する飼養方式では, 飼料利用効率 の改善効果以外にてれらの疾病の防止効果も考慮すべき であろう.

$\mathrm{SL}$ を $30 \mathrm{ppm}^{9} ， 33 \mathrm{ppm}^{10)}$ 添加給与した他の報告で は, 飼料摂取量が顕著に減少して要求率か改善されてい る. しかしながら, 本実験では SL-30 ppm 添加給与 区の第一胃液性状は他の 2 試験区之同様に推移したのに あかかわらず飼料摂取量の減少は小さく，改善効果はわ 
脇田・小林・星野・北林・橋村 $\cdot$ 工藤

Table 4. Effects of salynomycin(SL) and monensin(MN) on total volatile fatty acids and their composition, and acetate/propionate $(\mathrm{A} / \mathrm{P})$ ratio (Mean, $\mathrm{n}=7$ )

\begin{tabular}{|c|c|c|c|c|c|c|c|}
\hline & $\begin{array}{l}\text { Total VFA } \\
(\mathrm{m} \text { moles } / \mathrm{d} l)\end{array}$ & Acetic & Propionic & $\begin{array}{r}\text { Butyric } \\
(\mathscr{6})\end{array}$ & n-Valeic & i-Valeic & $\mathrm{A} / \mathrm{P}$ ratio \\
\hline \multicolumn{8}{|c|}{0 (Initial) } \\
\hline Control & 22.9 & 55.2 & 35.2 & 7.1 & Tr. & 2.6 & 1.58 \\
\hline SL-20 & 23.3 & $57.1^{\mathrm{a}}$ & $34.7^{\mathrm{ab}}$ & 6.8 & Tr. & 2.0 & 1.67 \\
\hline SL-30 & 22.1 & $54.8^{b}$ & $35.8^{\mathrm{a}}$ & 7.0 & Tr. & 2.5 & 1.55 \\
\hline $\mathrm{MN}-30$ & 24.7 & $58.2^{* \mathrm{a}}$ & 33.4 & 6.7 & Tr. & 1.9 & 1.77 \\
\hline \multicolumn{8}{|c|}{ After 61 days } \\
\hline Control & 22.1 & 50.3 & 41.2 & 6.4 & $\operatorname{Tr}$. & 2.2 & 1.27 \\
\hline SL-20 & 21.3 & $49.1^{\mathrm{a}}$ & $45.8^{* * *}$ & $4.1^{* *}$ & Tr. & 1.0 & $1.08^{* *}$ \\
\hline SL-30 & 16.2 & $50.9^{\mathrm{ab}}$ & $44.7^{* *}$ & $3.6^{*}$ & Tr. & 0.9 & 1.14 \\
\hline $\mathrm{MN}-30$ & 19.3 & $51.5^{b}$ & $44.1^{* *}$ & $4.0^{* *}$ & Tr. & $0.4^{* * *}$ & 1.17 \\
\hline \multicolumn{8}{|c|}{ After 119 days } \\
\hline Control & 23.9 & 46.0 & 42.4 & 9.2 & Tr. & 2.1 & 1.09 \\
\hline SL-20 & 19. $2^{* \mathrm{ab}}$ & $49.1^{* a}$ & $44.9^{*}$ & $4.4^{* * a}$ & Tr. & $1.4^{* * a b}$ & $1.10^{\mathrm{a}}$ \\
\hline $\mathrm{SL}-30$ & $17.7^{* * a}$ & $47.2^{b}$ & $46.0^{* *}$ & $5.6^{* * * a b}$ & Tr. & $1.2^{* * * \mathrm{a}}$ & $1.03^{\mathrm{ab}}$ \\
\hline $\mathrm{MN}-30$ & $22.4^{\mathrm{b}}$ & $46.0^{\mathrm{ab}}$ & $46.6^{* * *}$ & $5.7^{* * * \mathrm{~b}}$ & Tr. & $1.5^{*}$ & $0.99^{* * \mathrm{~b}}$ \\
\hline \multicolumn{8}{|c|}{ After 187 days } \\
\hline Control & 9.3 & 55.6 & 35.8 & 6.1 & 1.1 & 1.1 & 1.60 \\
\hline SL-20 & $16.6^{* * * a}$ & $47.4^{* *}$ & $45.1^{* * * a}$ & 5.5 & $0.4^{* * *}$ & 1.6 & $1.05^{* * a}$ \\
\hline SL-30 & $21.3^{* * * b}$ & $48.4^{*}$ & $44.1^{* * a b}$ & 5.8 & $0.2^{* * *}$ & 1.5 & $1.10^{* a b}$ \\
\hline $\mathrm{MN}-30$ & $15.0^{* * a}$ & 50.6 & $42.0^{* * b}$ & $5.2^{*}$ & $0.6^{*}$ & 1.6 & $1.21^{* b}$ \\
\hline \multicolumn{8}{|c|}{ After 244 days } \\
\hline Control & 25.3 & 52.2 & 39.0 & 5.3 & 0.9 & 2.6 & 1.35 \\
\hline SL-20 & $16.4^{* * *}$ & $51.0^{a}$ & $42.4^{a}$ & 3. $7^{* *}$ & 0.8 & 2.2 & $1.22^{\mathrm{a}}$ \\
\hline SL-30 & 13. $7^{* * *}$ & $50.1^{\mathrm{a}}$ & $42.9^{a}$ & $3.9^{*}$ & 0.8 & 2.3 & $1.18^{\mathrm{a}}$ \\
\hline $\mathrm{MN}-30$ & $17.9^{* *}$ & $55.5^{* * b}$ & $38.1^{\mathrm{b}}$ & $3.7^{*}$ & 1.2 & 1.5 & $1.46^{b}$ \\
\hline \multicolumn{8}{|c|}{ After 292 days } \\
\hline Control & 7.6 & 58.5 & 29.1 & 6.2 & 2.0 & 3.8 & 2.02 \\
\hline SL-20 & $11.3^{*}$ & $49.6^{* * a}$ & $42.9^{* * * a}$ & 4.2 & $0.6^{* a}$ & 2.3 & 1. $19^{* * * a}$ \\
\hline SL-30 & $11.5^{*}$ & $50.6^{* * a}$ & $44.0^{* * * a}$ & 3.5 & $0.7^{* \mathrm{a}}$ & $1.9^{*}$ & 1. $14^{* * * a}$ \\
\hline $\mathrm{MN}-30$ & 9.2 & $55.5^{\mathrm{b}}$ & $36.6^{* * \mathrm{~b}}$ & 4.4 & $1.4^{\mathrm{b}}$ & $2.1^{*}$ & $1.55^{* \mathrm{~b}}$ \\
\hline
\end{tabular}

$*, * *, * * *$ In each column differences from control are significant at 5,1 and $0.1 \%$ level.

a, b Values followed by different letters differ significantly at $5 \%$ level.

ずか $2 \%$ であった（表 2). この既報名10) との不一致の理 由は, この区で後半の体重に大きな個体差が見られたて とと関連があるように思われるが, 明確でない. RAUN らは，MN を 5.5 33 ppm 添加した完全配合飼料を 牛に不断給与した時に, 飼料効率が 10 17\% 改善され, 第一胃液のプロピオン酸割合が 5 10\% 增加し，乙の增 加は代謝エネルギー（ME）を 3〜6\% 増加したととに なるが, 飼料効率改善効果を全て説明できるものではな いとしている。 また，THORNTON と OWENs") は，牛に MN (200 mg/頭/日) を給与するとメタンとして消失 するエネルギーが約 10\% 減少し, ME が約 $5.2 \%$ 增加
するが, これはフィードロット牛で得られる MN の飼 料効率改善効果の半分を説明できるかす知れないと報告 している.酢酸, プロピオン酸, 酪酸へのヘキンースエ ネルギーの保持割合はそれぞれ 63, 109, 78\% であるこ とから, 本試験での VFA 組成割合（表 4）の平均値 （酶酸：プロピオン酸：酪酸＝対照区； $52.5: 37.5: 6.6$, SL-20 ppm 区 ； 49.2：44.2：4.4, SL-30 ppm区 ; $49.4: 44.3: 4.5, \mathrm{MN}-30 \mathrm{ppm}$ 区 $51.8: 41.5: 4.6$ ) から計算すると， SL-20 ppm, SL-30 ppm および MN-30 ppm 添加給与による VFA 組成割合の変更で VFA エネルギー量か対照区よりそれぞれ 4.4，4.8，2.9 
\% 增加したととになる.また, 本試験での蕽厚飼料要 求率の改善割合は, SL-20 ppm 区, SL-30 ppm 区, MN-30 ppm 区でそれぞれ 7,2，8\% であり（表 2), 浱厚飼料の TDNを75\% とすると増体俉要する飼料工 ネルギー量はそれぞれ 5.3，1.5，6.0\% 節約されたとと になるが, 上記の VFA エネルギーの増加割合と一致 しない.このことは上記の報告2,4) と同様に，第一胃内 の VFA 発醉パターンの変更による作用だけではイオ ノフォアの改善奻果を十分説明できないてとを示唆して

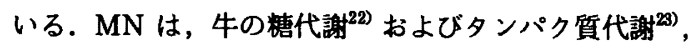
下部消化管でのタンパク質 ${ }^{23)}$ や軅粉 ${ }^{24)}$ の利用, 消化管 内容物の移動速度 ${ }^{25}$ など第一胃内発醉の変更と連動し た二次的な影敏も報告されているので, SL ゃ $\mathrm{MN}$ の 給与効果についてはてれらの要因も考察する必要があろ j.

上記のように，MN の多鮍にわたる試険報告に比べ SL に関するすのは非常に少ないが，著者らはSLにメ夕 ン生成抑制 ${ }^{26)}$, 第一胃内容物の移動速度の低下 ${ }^{27)}$ の作用があることを確認しており，牛に給与した場合の 作用効果は, ドウズレスポンスの差 $(\mathrm{SL}>\mathrm{MN})$ を除 き，両者に基本的な相運は無いものと思われる.

本研究経費の一部は文部省科学研究費補助金 (No. 61560326）によった.

\section{文献}

1) Dinius, D.A., M.E. Simpson and P.B. MARSH, J. Anim. Sci., 42: 229-234. 1976.

2) Raun, A.P., C.O. Cooley, E.L. Potter, R.P. RATHMACHER and L.F. RICHARDSON, J. Anim. Sci., 43:670-677. 1976.

3) Chalupa, W., W. Corbett and J.R. BreTHOUR, J. Anim. Sci., $51:$ 170-179. 1980.

4) Thornton, J.H. and F.N. Owens, J. Anim. Sci., $52:$ 628-634. 1981.

5) VAN Nevel, C.T. and D.I. Demeyer, Appl. Environ. Microbiol., 34:251-257. 1977.

6) Goodrich, R.D., J.E. Garret, D.R. Gast, M.A. Kirick, D.A. LARSON and J.C. MEISKE, J. Anim. Sci., $58:$ 1484-1498. 1984.

7）坂内良二・脇田正彰・星野自夫，日畜会報，50： 369-374. 1979.

8) Bergen, W.G. and D.B. Bates, J. Anim. Sci., $58: 1465-1483.1984$.

9）中嶋隆文 - 増野朋也 - 坂内良二 - 星野貞夫, 日音
会報, 53 : 541-546. 1982.

10) Mrrchen, N.R. and L.L. Berger, J. Anim. Sci., $60: 1338-1346.1985$.

11）川島良治・一瀬克章・斎田二郎，京大農畜栄美学 研業積, 第 54 号 : 1-16. 1979.

12）中村良一・米村寿男・須藤恒二編，牛の臨床検查 法. 1版. 8 章 1-74. 農文協. 東京. 1973.

13) Slyter, L.L., R.R. OltJen, D.L. Kern and F.C. Blank, J. Anim. Sci., 31 : 996-1002. 1970.

14) Chen, M. and M.J. Wolin, Appl. Environ. Microbiol., $38: 72-77.1979$.

15) Henderson, C., C.S. Stewart and F.V. NeKREP, J. Appl. Bacteriol., $51: 159-169$. 1981.

16) SaKauchi, R. and S. Hoshino, Z. Tierphysiol. Tiernährg. U. Futtermittelkde., 46 : 21-33. 1981.

17）星野貞夫 -脇田正彰・小林泰男 - 大久保正彦 - 中 䳋隆文・清水良彦・高野司郎・工藤英彦., 日畜 会報, 57：833-841. 1986.

18) Hoshino, S., M. Wakita and Y. Kobayashi, J. Anim. Physiol. a. Anim. Nutr., (In press)

19) Nagaraja, T.G., T.B. Avery, S.J. Galitzer and D.L. Harmon, Am. J. Vet. Res., 46 : 2444-2452. 1985.

20) Carlson, J.R., A.C. Hammond, R.G. BREEzE, M.J. POTCHOIBA and W.W. Heinemann, Am. J. Vet. Res., $44: 118-122$. 1983.

21) VAN MaAnan, R.W., J.H. Herbein, A.D. MCGilliad and J.W. Young, J. Nutr., 108: 1002-1007. 1978.

22) Poos, M.I., T.L. Hanson and T.J. KLopfenstein, J. Anim. Sci., $48:$ 1516-1524. 1979.

23) Rust, S.R. and F.N. Owens, J. Anim. Sci., 47 (Suppl) : 437. 1978.

24) Lemenager, R.P., F.N. Owens, B.J. SHOCKEY, K.S. LUSBY and T. ROBERT, J. Anim. Sci., 47 : 255-261. 1978.

25) Wakita, M. T. Masuda and S. Hoshino, J. Anim. Physiol. a. Anim. Nutr., (In press)

26) Kobayashi, Y., M. WaKata and S. Hoshino, J. Anim. Physiol. a. Anim. Nutr., 56 : 9096. 1986. 


\title{
Effects of Salinomycin and Monensin on Feed \\ Conversion of Concentrate and Ruminal Fluid \\ Characteristics in Fattening Holstein Steers
}

\author{
Masaaki Wakita, Yasuo Kobayashi, Sadao Hoshino, \\ Yoshimune Kitabayashi*, Motoo Hashimura** and Hidehiko Kudo** \\ Faculty of Agriculture, Mie University, Tsu-shi 514 \\ *Mie Prefectural Economy Federation of Agricultual \\ Cooperative, Tsu-shi 514 \\ ${ }^{* *}$ Kaken Pharmaceutical Co., Ltd., Chuoku 103
}

\begin{abstract}
Effects of salinomycin (SL) and monensin (MN) on feed conversion and ruminal fluid characteristics ( $\mathrm{pH}$, volatile fatty acids (VFA) and ammonia concentrations, and protozoa number) were investigated using 28 Holstein steers. The steers were allotted equally to the following four treatments : no treatment (control), $20 \mathrm{ppm} \mathrm{SL,} 30 \mathrm{ppm}$ SL and $30 \mathrm{ppm} \mathrm{MN}$ supplementations, and were fed one of these concentrate and rice straw ad libitum for 292 days starting from 7 months of age. Neither final body weights nor average daily gains were affected by the feeding of SL and $\mathrm{MN}$, but feed (concentrate) intake in steers fed $20 \mathrm{ppm} \mathrm{SL}, 30 \mathrm{ppm} \mathrm{SL}$ and $30 \mathrm{ppm}$ MN decreased so that feed conversion was improved by $7,2,8 \%$ respectively. There was no significant difference between the effects of supplemental $20 \mathrm{ppm}$ SL and $30 \mathrm{ppm}$ MN which were currently approved concentrations of these additives in Japan. The magnitude of improvement in feed conversion was markedly variable in feeding periods. In the initial period of the experiment ruminal fluid characteristics except for VFA composition were not altered notably by dietary SL and $\mathrm{MN}$, while in the later period ruminal $\mathrm{pH}$, ammonia concentration and acetate/propionate (A/P) ratio were lowered by supplemental SL or MN. The total number of protozoa was less than $10^{4} / \mathrm{ml}$ at the start of experiment, and was little affected by the supplementation of the ionophores.
\end{abstract}

Jpn. J. Zootech. Sci., 58 (5): 396-402, 1987

Key words : salinomycin, monensin, feed conversion, ruminal fluid, fattening steer 